\title{
Morphological evaluation of 108 strawberry cultivars - and consequences for the use of descriptors
}

\author{
Monika Höfer ${ }^{\mathrm{a}, *}$, Renee Drewes-Alwarez ${ }^{\mathrm{b}}$, Petra Scheewe ${ }^{\mathrm{b}}$ and Klaus Olbricht ${ }^{\mathrm{c}}$ \\ a Julius Kühn-Institute, Federal Research Centre for Cultivated Plants, Institute for Breeding, \\ Research on Horticultural and Fruit Crops, Dresden, Germany \\ ${ }^{\mathrm{b}}$ University of Applied Science, Dresden, Germany \\ ${ }^{\mathrm{c}}$ Hansabred GmbH \& Co. KG, Dresden, Germany
}

Received 19 March 2012; accepted 25 May 2012

\begin{abstract}
Strawberry cultivars in current commercial use have a very narrow genetic base and reduced morphological and genetic diversity that puts them at risk from disease and climate change. Germplasm collections hold examples of the agricultural biodiversity of small berries where they are conserved, characterized and made available to breeders to improve productivity. Phenological evaluations of existing strawberry cultivars provide information for use by breeders in developing cultivars with improved qualities and more diverse genetic background. Leaves, flowers and fruits are the most important morphological descriptors for identification of strawberry cultivars. A comprehensive catalogue of descriptors drawn up by UPOV and IPGRI served as the basis for evaluation of 108 cultivars in a field trial. Each plot consisted of 21 one-year-old plants per genotype and plants were evaluated once with a range of descriptors; 10 of plant and leaf morphology, 7 of the flower and 25 of the fruit.

On the basis of this comprehensive evaluation and data analysis, eighteen primary descriptors (plant, leaf, flower and fruit characteristics) independent of cultivation effects were selected for a large screening. Further descriptors for yield, inner fruit quality and disease resistance should be used as secondary descriptors as they are more environmentally influenced. These descriptors were proposed as appropriate primary and secondary descriptors for the European GENBERRY project of the cultivated strawberry (Fragaria x ananassa Duch.).
\end{abstract}

Keywords: Fragaria x ananassa Duch., evaluation, germplasm, genetic diversity, morphology, phenology, fruit quality, principal component analysis

\section{Introduction}

The cultivated strawberry Fragaria $\times$ ananassa Duch. $(2 n=8 \times=56)$ is the most important berry fruit crop worldwide. In 2009, strawberries were the 19th most important fruit crop worldwide (http://faostat.fao.org) with approximately 4.18 Million metric tonnes produced on 254,523 hectares of land. The leading countries of strawberry cultivation are the U.S.A. (1.27 million metric tonnes), Spain (292 thousand metric tonnes) and Turkey (264 thousand metric tonnes). The attractive strawberry fruits are favoured for their excellent taste and contain health promoting vitamins, minerals and antioxidative compounds [1]. In strawberry, domestication has led to a reduction of both morphological and genetic diversity. In Germany fruit production is dominated by only one cultivar, 'Elsanta'. Little is known about the diversity of more than 1,000 existing cultivars. In order to improve cultivars to meet new problems of

\footnotetext{
*Corresponding author: Monika Höfer, Julius Kühn-Institute, Federal Research Centre for Cultivated Plants, Institute for Breeding, Research on Horticultural and Fruit Crops, Pillnitzer Platz 3a, D-01326 Dresden, Germany. Tel.: +49 351 2616222; Fax: +49 351 2616213; E-mail: monika.hoefer@jki.bund.de.
} 
cultivation, it is essential to determine the range of traits available in the genetic resources of small berries. It is important to ensure that agricultural biodiversity of small berries is conserved, characterized and used to improve productivity.

Strawberry was chosen to be on the Annex 1 list of the International Treaty on Plant Genetic Resources for Food and Agriculture. Within the frame of the Global Crop Diversity Trust, an expert committee developed a document for 'Global Conservation Strategy for Fragaria (Strawberry)'. The most important part of the framework is the strategy for coordinating the Global conservation of strawberry genetic resources [2]. A standardized ontology for phenotypic and genotypic characterization of the collection and an optimised documentation of the passport and evaluation data is required to improve accessibility of the available genetic resources. Compared to other fruit species, relatively few reports exist about the evaluation of strawberry cultivar genetic resources. Based on literature in Prunus avium L. [3], Prunus armeriaca L. [4-6], Prunus cerasus L. [7] and Malus $x$ domestica Borkh. [8, 9] a strategy was designed for the characterization of a part of the strawberry genebank of the Institute for Breeding Research on Horticultural and Fruit Crops, Dresden-Pillnitz, Germany. The genebank consists of 278 strawberry cultivars preserved as potted plants under open field conditions. The collection consists of three groups of cultivars: (1) German cultivars, (2) cultivars with a social cultural, local or historical relation to Germany and (3) some international cultivars with important pomological traits.

Maintaining the genetic diversity of vegetatively propagated crops is more demanding than for most seed-producing plants because the specific genotype must be maintained. Primary collections of clonal crops are in the field or screened enclosures; however, backups for these materials are needed to provide security in case of a disease or environmental disaster. According to the Global Conservation strategy for Fragaria, each cultivar should be preserved with at least in one duplicate for safety [2]. In addition to the development of an effective conservation strategy for strawberry genetic resources in Germany [10,11] it is important to facilitate the characterization of the genetic diversity found within the entire collection and to develop core subsets $[12,13]$.

Various types of data were used to analyze the genetic diversity in the collections. Morphological and horticultural markers, useful for the distinction of the accessions, should be included in a descriptor list. Descriptors for characterizing and identifying strawberry cultivars were developed by the International Union for the Protection of New Varieties of Plants [14] and the International Board for Plant Genetic Resources [15]. Leaves, flowers and fruits are the most important morphological descriptors for identification of strawberry cultivars and wild species. Multivariate analysis is used to study germplasm of perennial fruit species: Malus $\times$ domestica Borkh. [8, 9], Prunus ameriaca L. [4-6], Prunus avium L. [3], Prunus cerasus L. [7, 16]. This technique is also used to study variability in crop species such as Eleusine coracana (L.) Gaertn. [17], Phaseolus vulgaris L. [18] and Phoenix dactylifera L. [19].

The objectives of this study were (1) a comprehensive evaluation of the Gene Bank material based on the catalogue of descriptors developed by UPOV (International Union for the protection of new varieties of plants) and IPGRI (International Plant Genetic Resources Institute) [14, 15]. (2) Use this data analysis to identify bottlenecks and to assess and select descriptors for a large screening of the strawberry cultivars in the Gene Bank of the Institute for Breeding Research on Horticultural and Fruit Crops in Dresden-Pillnitz and for future European projects.

\section{Material and methods}

\subsection{Plant material}

Strawberry cultivars (108) in the fruit genebank of the Institute for Breeding Research on Horticultural and Fruit Crops, Dresden-Pillnitz were included in the evaluation: Amazone, Anneliese, Aphrodite, Appetita, Aprikose, Arista, Aroma, Asiprima, Atomka, Aurora, Avant Tout, Bella, Bomba, Calea, Cambridge Favorite, Cambridge Late Pine, Desna, Deutsch Evern, Deutsch Everns Bromba, Direktor Paul Wallbaum, Dorena, Dresden, Early Bommel, Elsanta, Favette, Ferma, Festiva, Finessa, Fortuna, Frabella, Fraroma, Frasanta, Frikonsa, Fructana, Frühe aus Melitopol, Gärtner Pötschkes Jubilar Verbesserte, Gärtner Pötschkes Rotaroma, Gorella, Hansa, Hausgarten, Heinemanns Unerschöpfliche, Herbstfreude, Herzbergs Triumph, Hildegard Pötschke, Honeoye, Irvine, Jena 3, Joghana, Jucunda, Julyana, Junimorgen, Kaisers Sämling, Karla, Königin Luise, Laxtons Noble, Macherauchs Dauerernte, Mainperle, Marascor, Markee, Marloun, Marmolada, Merton Princess, Mieze Schindler, Mrak, Münchner Kindl, Murzinka, 
Natascha, Oberschlesien, Orion, Pajaro, Pantagruella, Panther, Papa Lange, Peltata, Pemica, Precoce di Romagna, Primek, Pyretta, Quellana, Redgauntlet, Reusraths Allerfrüheste, Rheingold, Rigensa, Rival, Rosella, Rosenta, Rubia, Schloß Horneburg, Senga Dulcita, Senga Sengana, Sieger, Silvia, Solotaya, Sonjana, Spadeka, Sparkles, Strawberry, Späte Leopold, Sturms Zuckersüße, Symphony, Tabea, Talisman, Thielesa, Tioga, Trumpeter, Weghorna, Weiße Ananas, Wunder von Köthen, Zarathustra. According to the passport data 76 cultivars were German cultivars. In a three years experiment (2004-2006) each cultivar was investigated once: Every year 35 to 37 cultivars randomly selected were studied in a field trial.

\subsection{Field plot design}

Each plot consisted of 21 one-year-old plants per cultivar planted in three rows. All plants were planted as fresh plants in August. Ten cultivars defined by UPOV were used as references [14]. The Institute for Breeding Research on Horticultural and Fruit Crops, Dresden-Pillnitz is located at $51^{\circ} 00$ “07” N latitude, and $13^{\circ} 52^{\prime} 59^{\prime}$ ' E longitude, altitude $115 \mathrm{~m}$. It has $9.1^{\circ} \mathrm{C}$ annual average temperature, and $668 \mathrm{~mm}$ annual precipitation. Due to anirrigation system plants could be cultivated at an optimum with regard to their demand on water. The soil type at the orchard is clayey sand with pH 5.6-6.6. No visible winter damages appeared in the years of investigation.

\subsection{Parameters studied}

The evaluation of all the cultivars was carried out by taking data on 31 of the descriptors established by UPOV [14] and IPGRI [15], 5 descriptors from the COST action 836 'Integrated research in berries' [20] and 6 descriptors selected by the project partners for their value for identification. These 42 descriptors consisted of: 10 morphological descriptors of the plant and the leaf, 7 of the flower and 25 of the fruit:

1. Plant: habit (IPGRI 4.1.1.): erect (3), intermediate (5), prostrate (7)

2. Leaf: color of upper side (IPGRI 4.2.): light (3), intermediate (5), dark (7)

3. Leaf: glossiness (UPOV 7): (3) weak, (5) medium, (7) strong

4. Terminal leaflet: shape of base (UPOV 9 adapted): (1) acute, (2) obtuse, (3) rounded, (4) acute-obtuse, (5) obtuse-rounded, (6) 1, 2 or 3

5. Terminal leaflet: shape of incisions of margin (UPOV 10 adapted): (1) serrate, (2) crenate, (3) serrate-crenate

6. Petiole: attitude of hairs (UPOV 11 adapted): (1) upwards, (2) slightly outwards, (3) strongly outwards, (4) upwards-slightly outwards, (5) slightly-strongly outwards, (6) upwards-strongly outwards

7. Stipule: anthocyan coloration (UPOV 12 adapted): (1) absent or very weak, (3) weak-medium, (5) mediumstrong, (7), strong-very strong

8. Stolons: number (UPOV 13): (1) very few, (3) few, (5) medium, (7) many

9. Time of appearance of first stolons (IPGRI 4.1.9.): (1) very early, (3) early, (5) intermediate, (7) late, (9) very late

10. Stolons: anthocyan coloration (UPOV 14 adapted): (1) absent or very weak, (3) weak-medium, (5) mediumstrong, (7) strong-very strong

11. Time of flowering $-50 \%$ of plants at first flower (UPOV 39; IPGRI 4.1.11.): (1) very early, (3) early, (5) intermediate, (7) late, (9) very late

12. Average number of flowers per inflorescence: counted and scored: (1) very few, (3) few, (5) intermediate, (7) high, (9) very high

13. Average number of inflorescences per plant (IPGRI 4.1.6.): counted and scored: (1) very few, (3) few, (5) intermediate, (7) high, (9) very high

14. Inflorescence: position relative to foliage (UPOV 16; IPGRI 4.1.7.): (1) beneath, (3) level with, (5) above

15. Flower: type (IPGRI 4.3.2.): (3) only female, (5) hermaphrodite

16. Flower: size (UPOV 17): (3) small, (5) medium, (7) large

17. Flower: size of calyx relative to corolla (UPOV 18): (3) smaller, (5) same size, (7) larger

18. Length of picking season - number of days 
19. Time of ripening $-50 \%$ of plants with ripe fruits (UPOV 40; IPGRI 4.1.12.): (1) very early, (3) early, (5) medium, (7) late, (9) very late

20. Yielding capacity IPGRI 6.2.5: (1) very low, (3) low, (5) intermediate, (7) high, (9) very high

21. Yield per plant: measured in grams (average)

22. Fruit: pedicel brittleness (IPGRI 4.4.5.): (3) low, (5) intermediate, (7) high

23. Fruit: position at harvest (IPGRI 6.2.1.): (3) on ground, (5) intermediate, (7) upright

24. Fruit: size (UPOV 22; IPGRI 4.4.1.): measured in mm (average of fruits) and scored (1) very small, (3) small, (5) medium, (7) large, (9) very large

25. Fruit: uniformity of size (IPGRI 6.2.7.): (3) low, (5) intermediate, (7) high

26. Fruit: predominant shape (COST 836 descriptor 13): (1) oblate, (2) globose, (3) globose conic, (4) ovoid, (5) cordiform, (6) long conic, (7) necked, (8) long wedge, (9) short wedge

27. Fruit: uniformity of shape (IPGRI 6.2.8.): (3) low, (5) intermediate, (7) high

28. Fruit: band without achenes (UPOV 25): (1) absent or very narrow, (3) narrow, (5) medium, (7) broad, (9) very broad

29. Fruit: color (COST 836 descriptor 18): (1) white, (3) orange/pink, (5) red, (7) dark red, (9) very dark red

30. Fruit: coloration type (IPGRI 6.2.11.): (3) starting at the calyx, (5) starting at the apex, (7) uniform

31. Fruit: glossiness (IPGRI 6.2.10.): (3) dull, (5) intermediate, (7) bright

32. Fruit: insertion of achenes (IPGRI 4.4.10.): (3) sunken, (5) level, (7) raised

33. Fruit: achene color (COST 836 descriptor 26): (1) green, (3) yellow, (5) red, (7) brown

34. Fruit: insertion of calyx (UPOV 31; IPGRI 4.4.4.): (1) in a basin, (2) with fruit level, (3) above fruit

35. Fruit: size of calyx in relation to fruit diameter (IPGRI 6.1.5.): (3) smaller, (5) same size, (7) larger

36. Fruit separation with or without swollen fleshy tissue of receptacle: (0) without, (1) with

37. Fruit: hollow center (UPOV 37): (3) absent or very weakly expressed, (5) weakly expressed, (7) strongly expressed

38. Fruit: color of flesh (IPGRI 4.4.7.): (1) white, (3) pale rose, (5) intermediate, (7) dark red, (9) very dark red

39. Fruit: firmness of fruit-flesh (COST 836 descriptor 24): (3) soft, (5) intermediate, (7) firm

40. Fruit: flavour (COST 836 descriptor 31): (1) without, (3) poor, (5) slight, (7) strong

41. Fruit: Relation of sweetness and acidity: (1) very sweet, (3) sweetish, (5) balanced, (7) acidulated, (9) very acid

42. Fruit: juiciness: (3) low, (5) intermediate, (7) high

For fruit evaluation the 25 descriptors were subdivided in three groups: 6 descriptors for orchard evaluation, 12 for fruit morphology and 7 for fruit quality. At maturity samples of 10-20 fruits per cultivar were hand harvested randomly and immediately transferred to the laboratory for evaluation.

In the first and the second experimental year the number of days from blossom to first picking day was recorded in detail as an additional phenological parameter.

\subsection{Data analysis}

Statistical analyses were performed using SAS 9.2. Frequencies of each class were calculated for the qualitative and scored quantitative parameters. Quantitative measurements were made of various traits of the cultivars to enable numerical analysis of the data (means and standard deviations). Spearmans's correlation coefficients were determined. Principal component analysis (PCA), [16, 21], was used to reveal the patterns of morphological variation within the strawberry germplasm collection. PCA was performed using the PRINCOMP procedure of the SAS Statistical Package 9.2.

\section{Results}

\subsection{Phenological data}

Although the 35 to 37 cultivars used each year were randomly selected, the picking season did not vary; it started in Dresden-Pillnitz from June 6th to 9th and ended July 10th to 14th. Based on the detail estimation of the Julian day 

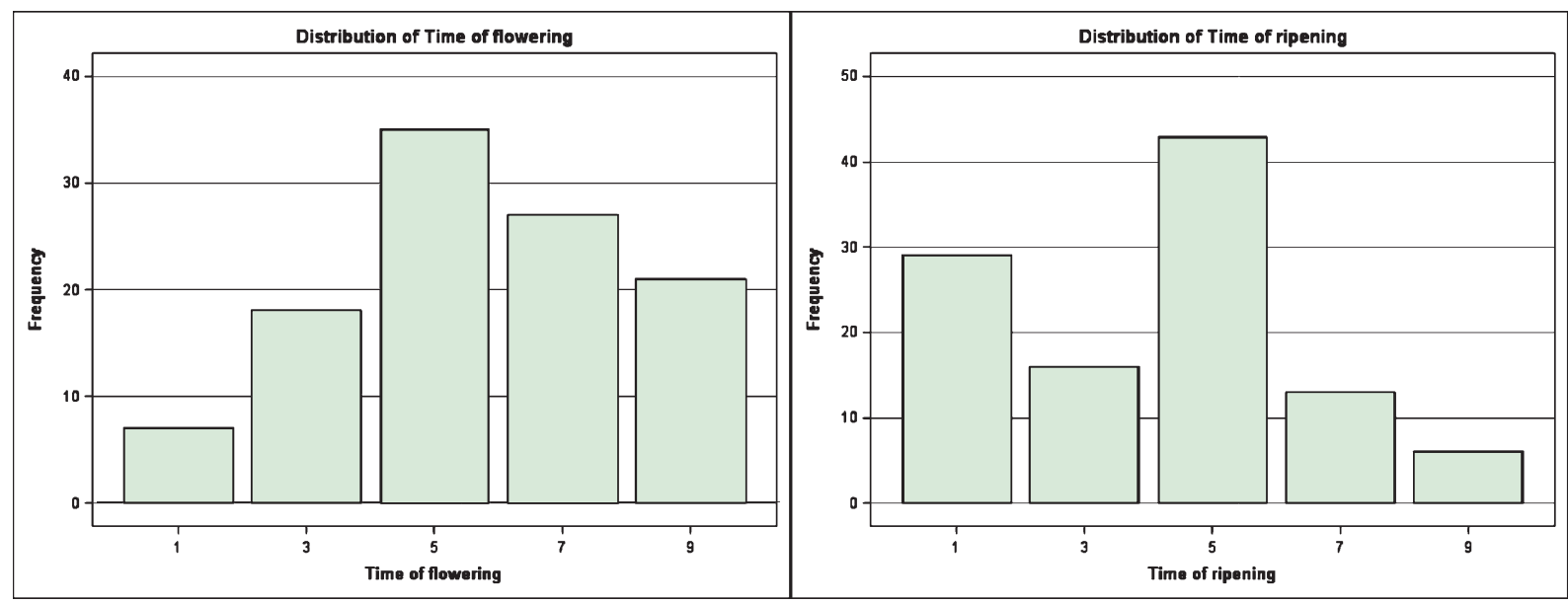

Fig. 1. Distribution of the time of flowering and time of ripening within the 108 tested strawberry cultivars (scores acc. to the method details).

number from blossom to the first picking, a negative correlation coefficient of -0.67 was estimated between time of ripening and the day number from full blossom to the first picking (data not shown). The group of late and very late flowering cultivars (23 days from the blossom to the first picking) include Direktor Paul Wallbaum, Junimorgen, Natscha, Orion and Tabea. In contrast, very early and early flowering cultivars like Heinemanns Unerschöpfliche, Weiße Ananas (45 days), Thielesa (47 days) and Amazone (52 days), demonstrated a very long time from blossom to first picking. Cultivars could be divided into three groups of flowering: very early/early ( 25 cvs.), medium (35 cvs.) and late/very late (48 cvs.) (Fig. 1). Seven cultivars belong to the group of very early flowering cultivars have flowers endangered by late spring frosts at the end of April/beginning of May: Anneliese, Aphrodite, Avant Tout, Deutsche Evern, Deutsch Everns Bromba, Heinemanns Unerschöpfliche, Sieger. In contrast to this, the higher frequency of the descriptor ripening time was found with the very early/early cultivars (45 cvs.) supporting the negative correlation. The length of picking time is an interesting parameter for commercial strawberry production. A high yield in a short picking season is highly valued. The length of picking time varied from 8-9 days (cvs. Hansa, Hildegard Pötschke and Cambridge Late Pine) to 32-33 days (cvs. Aroma, Precoce di Romagna, Pajaro), and as long as 42 days (Deutsch Evern). Under the conditions described, fruits of the commercial cv. Elsanta were picked for 22 days (data not shown).

\subsection{Characteristics of cultivars}

In this chapter selected descriptors are described and special cultivars are highlighted. For the quantitative parameters (Table 1) there was a dramatic difference between the minimum and maximum number of flowers per inflorescence and number of inflorescences per plant. The yield per plant varied by a factor of 38 . Fruit diameters nearly doubled and ranged from $23 \mathrm{~mm}$ (cv. Jena 3) to $43 \mathrm{~mm}$ (cv. Frasanta).

Table 1

Results of the measured quantitative five descriptors estimated in the frame of an evaluation of 108 strawberry cultivars

\begin{tabular}{lrrrlccc}
\hline Descriptor & Mean & $\begin{array}{c}\text { Std } \\
\text { error }\end{array}$ & $\begin{array}{c}\text { Minimum } \\
\text { value }\end{array}$ & Cultivars & $\begin{array}{c}\text { Maximum } \\
\text { value }\end{array}$ & $\begin{array}{c}\text { Cultivars } \\
\text { variation }(\%)\end{array}$ \\
\hline Number of flowers per inflorescence & 7.80 & 0.28 & 2.60 & Aphrodite & 17.80 & Avant Tout \\
Number of inflorescences per plant & 5.83 & 0.36 & 1.10 & Macherauchs Dauerernte & $\begin{array}{c}16.30 \\
\text { Peltata }\end{array}$ & 64.38 \\
Length of picking season (d) & 21.55 & 0.59 & 8.00 & Hansa, Hildegard Pötschke & 42.00 & Deutsch Evern & 27.87 \\
Yield per plant (g) & 222.15 & 15.54 & 17.29 & Aphrodite & 650.14 & Rosenta & 71.33 \\
Fruit: size (mm) & 31.54 & 0.34 & 22.50 & Jena 3 & 42.50 & Frasanta & 11.34 \\
\hline
\end{tabular}


Plant habit and leaves: The distribution of plant habit scores revealed 33 erect cultivars, 56 intermediate and 21 prostrate. The leaf color (upper side) was predominantly intermediate and three cultivars had a light coloration (cvs. Favette, Frühe aus Melitopol and Rigensa). The leaf glossiness was mainly weak (55 cvs.) and medium (48 cvs.); only five cultivars had a strong glossiness (cvs. Arista, Hildegard Pötschke, Königin Luise, Papa Lange and Spadeka). The terminal leaflet was dominated by an acute-obtuse ( 50 cvs.) and obtuse-rounded ( $27 \mathrm{cvs}$.) shape of the base. The anthocyanin coloration of the stipules was absent or weak-medium for $92 \%$ of the cultivars. Only six cultivars demonstrated a strong to very strong stipule coloration (cvs. Bomba, Hildegard Pötschke, Karla, Maucherauchs Dauerernte, Papa Lange, Precoce di Romagna). The time of the appearance of the first stolons was late and very late for $42 \%$ of the cultivars. Only 12 cultivars developed stolons very early (cvs. Aprikose, Aroma, Avant Tout, Early Bommel, Herbstfreude, Junimorgen, KöniginLuise, Mieze Schindler, MünchnerKindl, Papa Lange, Precoce di Romagna).

Flowers: In addition to counting the flower number per inflorescence and the number of inflorescences per plant, these two descriptors were also scored to represent the frequency distribution more clearly. Both parameters were most commonly very few/few: 88 cultivars had very few/few number of flowers per inflorescence and 91 cultivars had very few/few number of inflorescences per plant. Eleven cultivars developed a high/very high number of flowers per inflorescence (cvs. Calea, Junimorgen, Macherauchs Dauerernte, Mieze Schindler, Oberschlesien, Papa Lange, Rheingold, Spadeka and Späte Leopold). In contrast, only five cultivars had a high number of inflorescences per plant (cvs. Deutsch Everns, Bromba, Frikonsa, Pantagruella, Peltata and Rosenta). The position of the inflorescence relative to the foliage was at the same level for 54 cultivars. Nine cultivars had only female flowers (cvs. Direktor Paul Wallbaum, Junimorgen, Macherauchs Dauerernte, Mieze Schindler, Papa Lange, Precoce di Romagna, Späte Leopold, Tabea, Wunder von Köthen). The flower size was mostly scored as medium (65 cvs.). The size of the calyx relative to the corolla was identical for 61 cultivars.

Fruits: In addition to measuring the yield per plant in grammes, this descriptor was also scored to represent the frequency distribution more clearly. Yield was predominantly very low ( $25 \mathrm{cvs}$.), low (33 cvs.) and intermediate (36 cvs.). Only $11 \%$ of the cultivars demonstrated a high or very high yielding capacity under the experimental conditions. The highest value was found in the cv. Orion (626 g per plant) and cv. Rosenta (650 g per plant); cv. Elsanta $264 \mathrm{~g}$ per plant. The estimated correlation coefficient between measured and scored yield accounted for 0.96 . The same procedure was applied for the descriptor fruit size. However, the correlation coefficient was only 0.44 . Fruit size was dominated by small (43 cvs.) and medium scores ( 38 cvs.); only two cultivars demonstrated a very large size - cv. Ferma $(40 \mathrm{~mm})$ and cv. Frasanta $(43 \mathrm{~mm})$; cv. Elsanta $33 \mathrm{~mm}$. The brittleness of the pedicel was intermediate for 61 cultivars (56\%). The position of the fruit at harvest was mainly at the ground and intermediate levels (104 cvs. 96\%), only 4 cultivars had the fruits held upright (cvs. Reusraths Allerfrüheste, Desna, Julyana, Spadeka).

Six important parameters describing the morphology of fruit are summarized in Fig. 2. The cordiform shape appeared in $28 \%$ (5-30 cvs.), the short wedge shape in 19\% (9-21 cvs.), the globose conic form in $17 \%$ (3-18 cvs.) and the oblate form in 14\% (1-15 cvs.) of the cultivars (Fig. 2A). The uniformity of the shape was as high as $60 \%$ in these cultivars. In contrast, size uniformity scores were distributed over the entire range. The descriptor 'band without achenes' (Fig. 2B) was dominated by the score 1 (absent or very narrow - 29 cvs.), score 3 (narrow - 26 cvs.) and score 5 (medium - 34 cvs.). Two cultivars had a very broad band without achenes (cvs. Heinemanns Unerschöpfliche and Kaisers Sämling). Red colour was seen for 38 (35\%) of the cultivars (Fig. 2C), one was white (cv. Weiße Ananas) and four were very dark red (cvs. Deutsch Everns, Bromba, Frikonsa, Hildegard Pötschke, Precoce di Romagna). The coloration type of the fruits was mostly a uniform coloration ( 54 cultivars). For 43 cultivars the coloration started at the calyx and only 11 cultivars had a coloration starting at the apex. Intermediate to bright glossiness was evident for $94 \%$ of the cultivars, only four were dull (cvs. Aurora, Cambridge Late Pine, Münchner Kindl, Weiße Ananas; Fig. 2D). Insertion of the achenes showed a distribution over all scores; sunken, level and raised (Fig. 2E). For 64\% of the cultivars the color of the achenes was red. For 55 of the cultivars the size of the calyx was the same as the fruit (Fig. 2F). The descriptor insertion of the calyx was evenly distributed among the scores: in a basin, with fruit level and above fruit (data not shown).

Figure 3 demonstrates morphological parameters describing the inside of the fruit and descriptors characterizing the fruit quality. For 49 cultivars the fruit separation was found to include the swollen fleshy tissue of the receptacle and for 59 cultivars it did not. The colour of flesh was mainly pale rose (32 cvs.) and intermediate (30 cvs.), while six cultivars had a white flesh (cvs. Aurora, Deutsch Evern, Kaisers Sämling, Papa Lange, Rheingold, Weiße Ananas) and two cultivars were very dark red (cvs. Aroma, Precoce di Romagna; Fig. 3A). Seventy seven cultivars had an 

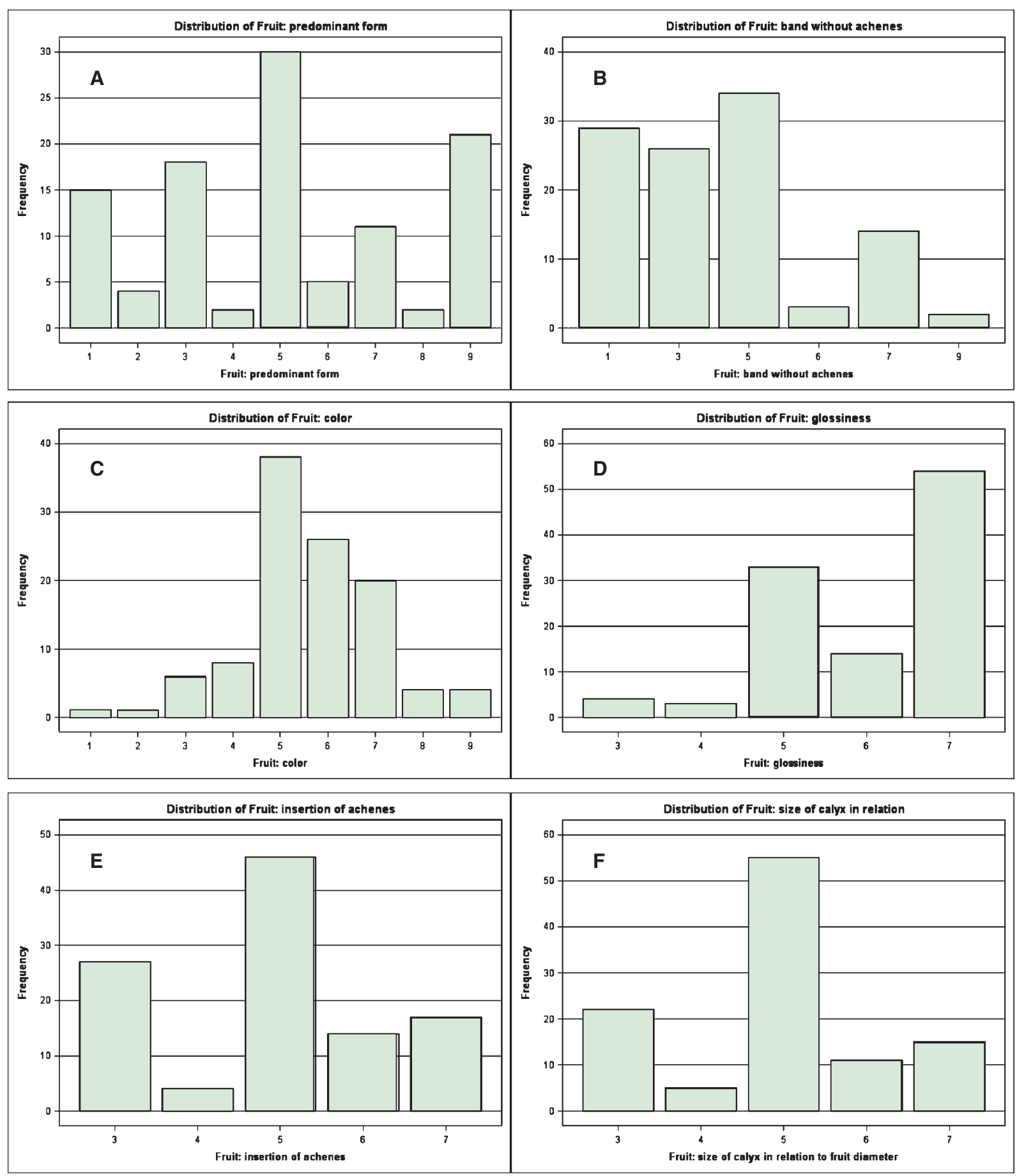

Fig. 2. Distribution of six parameters describing the morphology of the fruit within the 108 tested strawberry cultivars (scores acc. to the method details). 

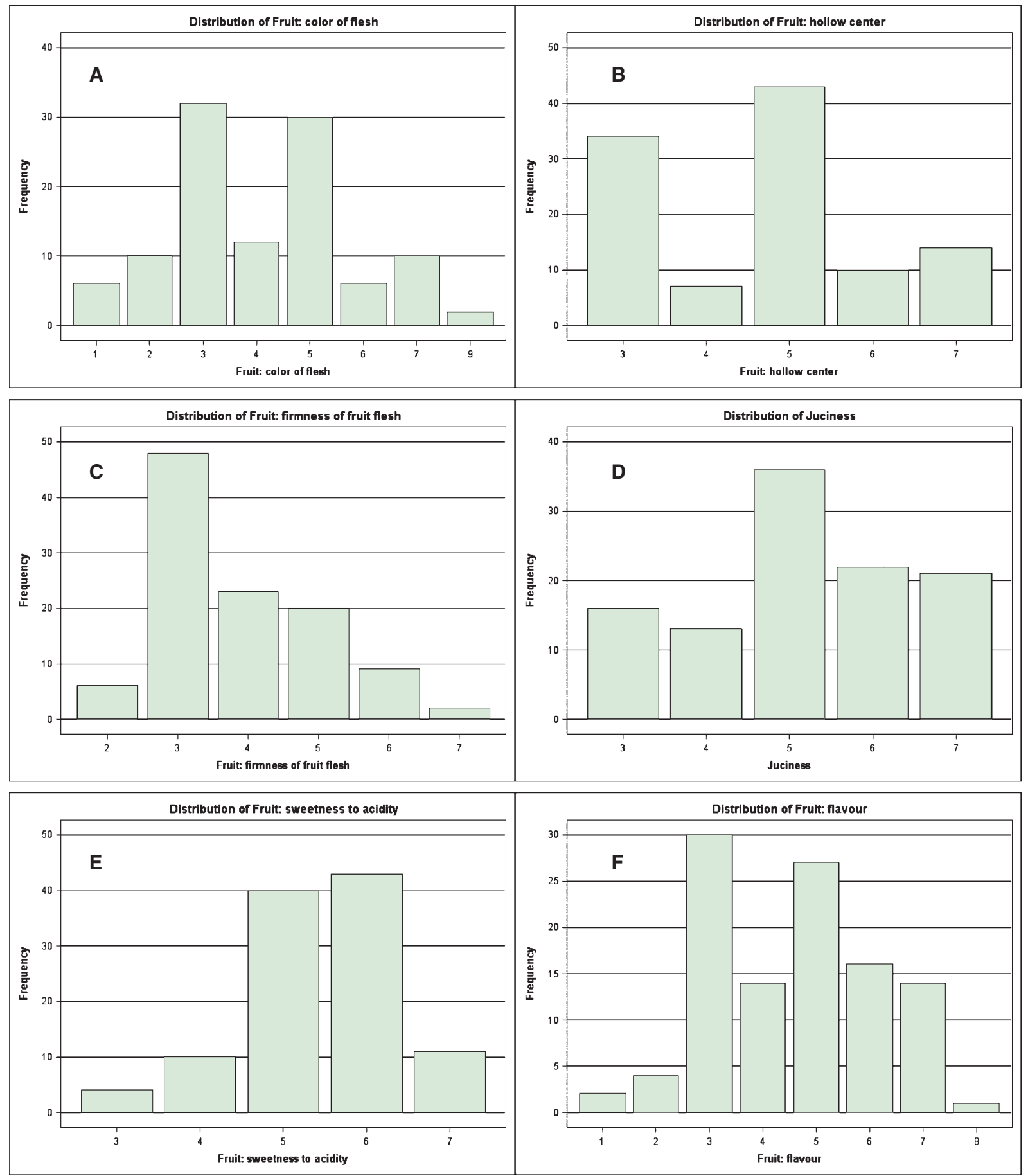

Fig. 3. Distribution of the descriptors for inner fruit morphology and fruit quality within the 108 tested strawberry cultivars (scores acc. to the method details). 
absent to weakly expressed hollow center (Fig. 3B). The firmness of the fruit flesh was mainly scored as soft firmness (Fig. 3C) and only two cultivars were firm (cvs. Irvine, Rosenta). In contrast, the descriptor juiciness was more evenly distributed (Fig. 3D). The two parameters estimated by tasting showed mostly balanced, lightly acidic fruits (Fig. 3E) with a poor to light flavour. The cultivar with very strong flavour was cv. Mieze Schindler.

\subsection{Correlations among variables}

All 42 parameters were included in the correlation analysis (data not shown). In general, the correlations among variables were comparatively low. Table 2 includes only descriptors showing correlation coefficients with values greater than 0.4. Sixteen correlation coeffecients were estimated greater than 0.4 . Three complexes of correlations were evident: (1) Flower/inflorescence/stolon; The number of flowers per inflorescence was positively correlated to the stolon number. A high number of inflorescences per plant which also generated a high yield $(r=0.66)$ affected the number of stolons negatively. Interestingly, cultivars having only female flowers produced fewer flowers per inflorescence $(r=-0.41)$ and the flower size was positively correlated to the fruit size $(r=0.44)$. (2) Yield; The yield was affected negatively by the plant habit. Cultivars having an erect habit had less yield per plant $(r=-0.56)$. In addition, the yield per plant was positively correlated to the fruit size $(r=0.47)$ and the length of the picking time $(r=0.43)$. (3) The third complex of correlations included relations to the fruit traits. The color of the fruit was highly positively correlated to the color of flesh $(r=0.66)$. The size of the band without achenes was bigger when the achenes were raised $(r=0.45)$ and the calyx was above the fruit $(r=0.63)$. In addition some unexpected correlations were noted; fruit glossiness was brighter when the yield was higher $(r=0.45)$ and the plant habit was more erect $(r=-0.42)$. Only low correlations could be observed for the firmness of the fruit to the juiciness $(r=0.37)$, fruit size $(r=0.34)$ and fruit color $(r=0.12)$.

\subsection{Principal component analysis}

Using PCA over the Correlation Matrix of 34 quantitative variables (ordinal and interval-scaled), the first 12 principal components (PC) of the cultivar data accounted for $70 \%$ of the total variance among cultivars with eigenvalues 1 (Table 3). According to the Scree-Test the first six PCs considered for Table 4 accounted for $48.53 \%$ of variablity. Main sources of variability, i.e. with the highest eigenvectors in each PC, were as follows:

PC1: Yield per plant, number of inflorescences per plant, fruit firmness and plant habit (negative value)

PC2: Flower size of calyx relative to corolla, number of flowers per infloresence, number of stolons, time of ripening, fruit size

PC3: Leaf color of upper side, inflorescence position relative to foliage, petiole attidude of hairs (negative value), time of flowering (negative value)

PC4: Fruit color and color of flesh, band without achenes (negative value), insertion of calyx (negative value)

PC5: Fruit insertion of achenes, uniformity of shape (negative value), pedicel brittleness, anthocyanin coloration of stolons

PC6: Fruit position at harvest and size (negative value), flower: size (negative value)

All fruit quality descriptors as flavour, relation of sweetness to acidity and juiciness, had little influence in the first six PCs.

Component scores for the cultivars evaluated are shown in Table 5. High values in PC1 indicated varieties with higher yield, higher number of inflorescences per plant, higher firmness and an erect plant habit. Cultivars such as Rosenta and Rosella belonged to this group. In contrast the cultivars Papa Lange and Münchner Kindl had a prostrade habit, less yield, a low number of inflorescences per plant and a low firmness value. The highest PC2 values corresponded to cultivars with a bigger fruit size as well as size of calyx relative to corolla, higher number of flowers per infloresence, number of stolons and a later time of ripening, such as cvs. Spadeka and Rubia, in contrast cvs. Aphrodite and Trumpeter. The highest PC4 values indicated the most colored fruits and flesh, the band without achenes is absent or very narrow and the calyx is in a basin. Cvs. Precoce di Romagna, Mieze Schindler, Macherauchs Dauerente belonged to this group. 

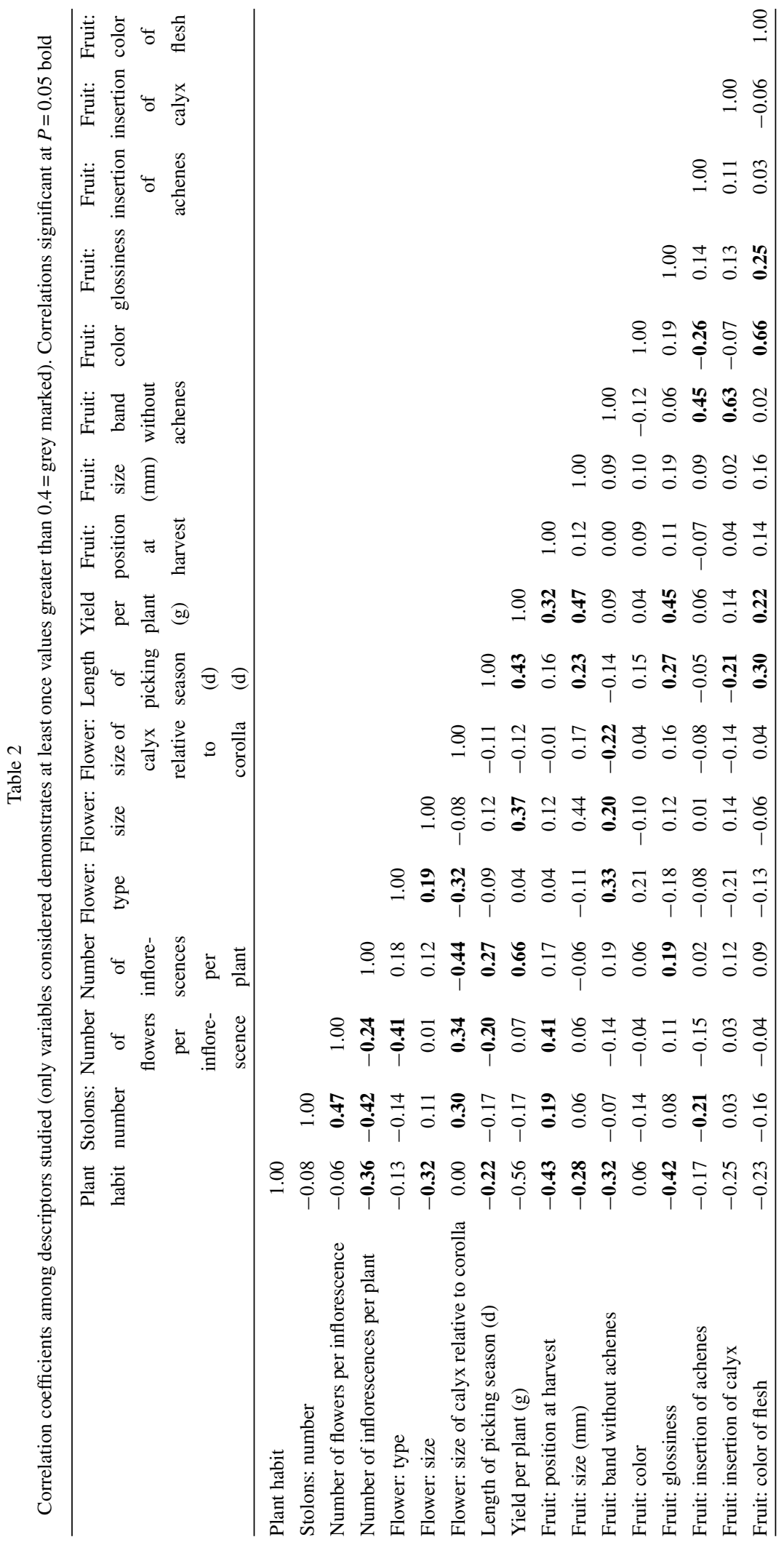
Table 3

Eigenvalues and portion of total variability among strawberry cultivars as explained by the first 12 principal components (PC)

\begin{tabular}{lccc}
\hline PC & Eigenvalues & Percent var. & Cumulative \\
\hline 1 & 4.29 & 12.61 & 12.61 \\
2 & 3.14 & 9.22 & 21.83 \\
3 & 2.79 & 8.21 & 30.05 \\
4 & 2.74 & 8.05 & 38.1 \\
5 & 1.85 & 5.46 & 43.55 \\
6 & 1.66 & 4.88 & 48.43 \\
7 & 1.58 & 4.64 & 53.07 \\
8 & 1.30 & 3.83 & 56.9 \\
9 & 1.23 & 3.63 & 60.53 \\
10 & 1.19 & 3.5 & 64.03 \\
11 & 1.16 & 3.41 & 67.44 \\
12 & 1.03 & 3.02 & 70.46 \\
\hline
\end{tabular}

\section{Discussion}

Compared to other fruit species the dessert strawberry Fragaria $\times$ ananassa has a short history. The two monographs by Duchesne $(1766,1788)$ should be considered landmarks in research on strawberries, especially the chapters on systematic and taxonomy [22]. Although a large number of cultivars are available in genebanks, it is now clear that the preservation of cultivars cannot be ensured by horticultural production and marketing. The maintenance of cultivars in genebanks is an important option. There is a growing interest in utilization of native germplasm in breeding programmes. For both applications a comprehensive evaluation is of great importance. Studies evaluating the diversity in Fragaria wild species used different leaf descriptors [23] as well as fruit and flowers traits [24, 25]. Compared to other fruit species, there are only a few reports of the evaluation of strawberry cultivar genetic resource. Faedi and co-worker published a Strawberry Cultivar Monography [26] of 129 cultivars released in 17 countries. A wide spectrum of descriptors of the plant, the leaf, flowers, fruits and for post harvest were used, but only new cultivars were considered. During the COST (European Cooperation in the field of Scientific and Technical Research) Action 836, a regional, inter-country network for genetic resources in strawberry in Europe was established, the first European inventory was developed and first arrangements for developing common descriptors were made [20].

According to a questionnaire enclosed in the Global Conservation Strategy for Fragaria (Strawberry) [2] the Fruit Genebank of the Julius Kühn-Institute, Institute for Breeding Research on Horticultural and Fruit Crops in Dresden has one of the largest European collections with 278 strawberry cultivars and 295 Fragaria wild species accessions. In the present article, the evaluation of 108 cultivars using 42 traits demonstrated a wide spectrum of morphological variation between these cultivars (Figs 1-3). To our knowledge, it is the first time that an evaluation of these descriptors was made with cultivars. This study included old cultivars with a social cultural, local or historical relation, and international cultivars with important pomological traits. The values for the cultivar Elsanta, the main production cultivar in Middle Europe, corresponded with the highest frequency for most of the descriptors (Figs 1-3), except for higher than average firmness and juiciness. The absolute values of yield and fruit size are very strongly dependent on the environmental condition [27, 28]. It has to be considered that the experiment was not realized in an intensive culture for strawberry production. A small additional experiment with the cultivars Anneliese and Deutsch Everns Bromba, (donor material originated from orchard propagation, in vitro culture and in vitro cold storage respectively) revealed differences particularly in the yield and the number of inflorescences per plant (data not shown). This observation confirmed the strong correlation within yield and number of inflorescences per plant (Table 2).

No significant correlations were found among descriptors related to phenology, flowering and ripening time. Contrary results were reported for apricots with correlations between harvest season and fruit descriptors like fruit weight, pit weight, brix or total acidity [4-6]. Differences between the results were explained by different ecogeographical 
Table 4

Eigenvectors associated with the first six principal components (PC) estimated from the correlation matrix of 34 descriptors

\begin{tabular}{|c|c|c|c|c|c|c|}
\hline \multirow[t]{2}{*}{ Descriptor } & \multicolumn{6}{|c|}{ Eigenvectors } \\
\hline & $\mathrm{PC} 1$ & $\mathrm{PC} 2$ & PC3 & $\mathrm{PC} 4$ & PC5 & PC6 \\
\hline Plant habit & -0.33 & -0.15 & -0.06 & 0.16 & 0.07 & -0.15 \\
\hline Leaf: color of upper side & 0.10 & -0.07 & 0.35 & 0.05 & 0.14 & 0.02 \\
\hline Leaf: glossiness & 0.05 & 0.22 & 0.14 & -0.12 & 0.12 & -0.04 \\
\hline Petiole: attitude of hairs & -0.03 & -0.04 & -0.30 & -0.03 & -0.04 & -0.27 \\
\hline Stipule: anthocyanin coloration & -0.08 & 0.10 & 0.12 & 0.26 & 0.12 & 0.03 \\
\hline Stolons: number & -0.18 & 0.34 & 0.11 & -0.10 & -0.19 & 0.17 \\
\hline Time of appearence of first stolons & 0.20 & -0.10 & -0.05 & -0.06 & 0.25 & -0.18 \\
\hline Stolons: anthocyan coloration & -0.05 & -0.07 & 0.24 & 0.13 & 0.30 & 0.03 \\
\hline Time of flowering & 0.13 & 0.18 & -0.29 & 0.11 & 0.27 & 0.12 \\
\hline Number of flowers per inflorescence & -0.12 & 0.30 & 0.28 & -0.04 & 0.01 & 0.22 \\
\hline Number of inflorescences per plant & 0.27 & -0.24 & 0.24 & -0.09 & 0.02 & -0.07 \\
\hline Inflorescence: position rel. to foliage & -0.06 & -0.21 & 0.30 & -0.05 & 0.19 & 0.08 \\
\hline Flower: size & 0.13 & 0.24 & 0.08 & -0.22 & -0.03 & -0.31 \\
\hline Flower: size of calyx rel. to corolla & -0.10 & 0.33 & -0.07 & 0.17 & -0.03 & 0.16 \\
\hline Length of picking season (d) & 0.25 & 0.00 & 0.02 & 0.21 & 0.07 & -0.01 \\
\hline Time of ripening & -0.07 & 0.31 & -0.15 & 0.00 & 0.27 & -0.14 \\
\hline Yield per plant $(\mathrm{g})$ & 0.38 & 0.08 & 0.17 & -0.06 & -0.02 & -0.13 \\
\hline Pedicel: brittleness & 0.13 & -0.01 & -0.16 & 0.09 & 0.35 & 0.29 \\
\hline Fruit: position at harvest & 0.15 & 0.16 & 0.23 & -0.03 & 0.02 & 0.33 \\
\hline Fruit: size $(\mathrm{mm})$ & 0.20 & 0.33 & -0.05 & 0.00 & 0.01 & -0.30 \\
\hline Fruit: uniformity of size & 0.13 & 0.06 & -0.12 & 0.06 & -0.16 & 0.06 \\
\hline Fruit: uniformity of shape & 0.11 & 0.06 & -0.18 & -0.07 & -0.32 & 0.17 \\
\hline Fruit: band without achenes & 0.14 & -0.02 & -0.09 & -0.40 & 0.12 & 0.07 \\
\hline Fruit: color & 0.10 & -0.03 & 0.13 & 0.37 & -0.18 & -0.11 \\
\hline Fruit: glossiness & 0.27 & 0.09 & 0.10 & 0.10 & -0.11 & 0.23 \\
\hline Fruit: insertion of achenes & 0.12 & 0.00 & -0.21 & -0.18 & 0.38 & 0.20 \\
\hline Fruit: insertion of calyx & 0.11 & -0.05 & 0.00 & -0.31 & -0.14 & 0.10 \\
\hline Fruit: size of calyx in rel. to fruit & -0.01 & 0.07 & 0.10 & -0.24 & -0.07 & -0.01 \\
\hline Fruit: hollow center & -0.10 & 0.23 & 0.06 & 0.07 & 0.17 & -0.10 \\
\hline Fruit: color of flesh & 0.21 & 0.04 & 0.05 & 0.34 & -0.12 & -0.02 \\
\hline Fruit: firmness of the fruit flesh & 0.29 & 0.10 & -0.10 & 0.03 & -0.12 & -0.09 \\
\hline Fruit: flavour & -0.13 & 0.26 & 0.17 & -0.03 & 0.10 & -0.26 \\
\hline Fruit: sweetnessbrix to acidity & 0.03 & 0.01 & -0.21 & 0.14 & -0.07 & 0.27 \\
\hline Fruit: Juiciness & 0.24 & -0.03 & -0.07 & 0.22 & 0.09 & -0.11 \\
\hline
\end{tabular}

groups of apricots and the size of the groups of cultivars studied. Like other diversity studies, most of the significant correlations greater than 0.4 were found among the fruit variables. The highest correlation $(r=0.66)$ was for fruit color and color of flesh. Comparable values were estimated for apricots Prunus armeniaca [5, 6].

In strawberry, domestication resulted in a reduction of both morphological and genetic diversity. Commercial fruit production is dominated by only few cultivars. At the same time consumers often claim that older cultivars used to have a better fruit quality, and they consider modern fruits too hard and tasteless. For determining the long-term trends in changes, correlations of the descriptors and the year of origin of the cultivars were calculated (Table 6). The 108 cultivars of the present experiment represent a time frame of 146 years with cvs. Jucanda from 1854 being the oldest and Frasanta from 2000 the latest. Within these 42 descriptors, 14 significant correlations could be estimated between morphological and pomological traits and the year of origin of the cultivars. Modern cultivars tended to 
Table 5

Component scores for 104 strawberry cultivars as a result of PCA

\begin{tabular}{|c|c|c|c|c|c|c|c|c|c|}
\hline \multirow[t]{2}{*}{ Cultivar } & \multicolumn{4}{|c|}{ Component scores } & \multirow[t]{2}{*}{ Cultivar } & \multicolumn{4}{|c|}{ Component scores } \\
\hline & $\mathrm{PC} 1$ & PC2 & PC3 & $\mathrm{PC} 4$ & & PC1 & PC2 & PC3 & PC4 \\
\hline Amazone & -0.83 & -0.91 & 0.24 & -0.23 & Königin Luise & -1.99 & 0.93 & 0.90 & 0.41 \\
\hline Anneliese & -0.23 & 0.12 & 1.71 & 0.06 & Laxtons Noble & -0.53 & -0.35 & -0.52 & -0.76 \\
\hline Aphrodite & -0.88 & -2.83 & -0.15 & 0.66 & Macherauchs Dauerernte & -1.43 & 1.37 & 0.70 & 2.07 \\
\hline Appetita & 0.11 & -0.22 & 0.04 & -0.21 & Mainperle & 0.01 & -0.39 & 0.06 & -1.61 \\
\hline Aprikose & -0.88 & 0.72 & -0.08 & -1.08 & Marascor & 1.46 & -0.30 & 0.26 & -1.61 \\
\hline Arista & 1.43 & 0.63 & 2.49 & -0.58 & Markee & -0.12 & -0.31 & 0.51 & 0.68 \\
\hline Aroma & 1.41 & 1.63 & 0.37 & 1.86 & Marloun & -0.18 & -0.22 & 0.67 & -1.13 \\
\hline Asiprima & 0.38 & -1.23 & 0.26 & 0.00 & Marmolada & 0.96 & 0.00 & -0.70 & 0.69 \\
\hline Atomka & -0.82 & -0.05 & -1.40 & 0.58 & Merton Princess & -0.91 & -0.10 & 0.32 & -0.37 \\
\hline Aurora & -0.91 & -0.85 & -1.30 & -0.62 & Mieze Schindler & -0.48 & 1.90 & 0.42 & 2.03 \\
\hline Avant Tout & -1.29 & 1.03 & 0.53 & -0.57 & Münchner Kindl & -2.56 & 0.07 & 0.48 & 0.13 \\
\hline Bella & 0.27 & -0.31 & -1.38 & 0.11 & Murzinka & -0.39 & -0.02 & -0.39 & -1.16 \\
\hline Bomba & 0.13 & -0.03 & -1.69 & 0.78 & Natascha & 0.94 & -0.63 & 1.80 & 0.26 \\
\hline Calea & 1.52 & 1.72 & -0.64 & -0.30 & Oberschlesien & -0.11 & 1.18 & -0.21 & 0.31 \\
\hline Cambridge Favorite & 0.14 & 0.99 & 0.09 & -1.32 & Orion & 1.52 & 0.65 & 0.88 & -1.03 \\
\hline Cambridge Late Pine & -2.09 & 0.59 & 0.03 & -0.27 & Pajaro & 1.06 & 0.03 & 0.93 & 0.41 \\
\hline Desna & 1.34 & -0.60 & 0.43 & -0.73 & Panther & -0.90 & -1.45 & 0.82 & 0.12 \\
\hline Deutsch Evern & -0.31 & -0.74 & 0.33 & 0.38 & Papa Lange & -2.10 & 1.13 & 1.50 & 0.59 \\
\hline Deutsch Everns Bromba & 1.44 & -0.69 & 2.17 & 1.32 & Peltata & 1.28 & -0.10 & 1.31 & -0.85 \\
\hline Direktor Paul Wallbaum & 0.52 & -1.54 & 0.89 & -0.36 & Pemica & 0.93 & -0.91 & -1.40 & -0.69 \\
\hline Dorena & 0.57 & 0.69 & -0.20 & -0.96 & Precoce di Romagna & -0.11 & -0.29 & 2.30 & 3.07 \\
\hline Dresden & -0.80 & 0.38 & 0.37 & 0.01 & Primek & 0.53 & 0.34 & -0.74 & 0.47 \\
\hline Early Bommel & -1.17 & -0.13 & -0.26 & -0.11 & Pyretta & -0.10 & -1.24 & -1.62 & 0.16 \\
\hline Elsanta & 0.70 & 0.12 & -0.56 & 0.38 & Quellana & 0.13 & -0.89 & 1.40 & 0.03 \\
\hline Favette & 0.15 & -1.43 & -2.33 & 0.40 & Redgauntlet & 0.05 & -0.35 & -0.87 & 1.33 \\
\hline Ferma & 1.16 & 0.72 & -0.31 & -0.42 & Reusraths Allerfrüheste & 1.05 & 0.02 & 0.81 & 1.48 \\
\hline Festiva & 0.99 & 0.09 & -1.76 & 1.85 & Rheingold & -0.82 & 1.22 & 0.98 & -2.00 \\
\hline Finessa & 0.67 & -1.08 & 0.22 & -0.71 & Rigensa & -0.09 & 0.07 & -2.14 & -0.90 \\
\hline Fortuna & -0.02 & 0.56 & 0.56 & -0.69 & Rival & -0.46 & -0.59 & -1.03 & 0.30 \\
\hline Frabella & 0.86 & 1.75 & -1.29 & -0.11 & Rosella & 1.65 & -0.50 & 1.29 & -1.42 \\
\hline Fraroma & 0.67 & 0.71 & -0.36 & -0.47 & Rosenta & 2.14 & -0.50 & -0.34 & -0.70 \\
\hline Frasanta & 0.32 & 1.61 & -0.70 & -0.21 & Rubia & 1.35 & 2.04 & -1.62 & -0.61 \\
\hline Frikonsa & 1.58 & -0.15 & 0.72 & 0.68 & Schloß Horneburg & 1.48 & -1.58 & -0.20 & -0.17 \\
\hline Fructana & -0.33 & -1.70 & 0.68 & -0.60 & Senga Dulcita & 0.24 & -0.01 & -1.15 & 1.07 \\
\hline Frühe aus Melitopol & -1.18 & -0.59 & -1.68 & 0.00 & Senga Sengana & 1.11 & 0.67 & -0.39 & 0.66 \\
\hline Gärtner Pötschkes Jubilar Verbesserte & -0.72 & -1.85 & -1.31 & 0.49 & Sieger & -0.97 & 0.19 & 0.42 & -0.91 \\
\hline Gärtner Pötschkes Rotaroma & -0.02 & -0.75 & -0.79 & -0.24 & Silvia & 0.84 & -0.96 & 0.37 & 0.05 \\
\hline Gorella & 0.17 & -0.55 & -0.50 & 0.26 & Solotaya & 0.64 & 0.28 & -1.07 & 0.98 \\
\hline Hansa & -1.80 & 0.25 & -0.61 & 0.56 & Sonjana & -0.69 & -1.12 & -1.29 & 1.06 \\
\hline Hausgarten & -0.31 & -1.26 & 1.46 & 1.15 & Spadeka & 0.08 & 2.14 & 0.16 & -0.82 \\
\hline Heinemanns Unerschöpfliche & -0.89 & -0.66 & 0.26 & -2.00 & Sparkles Strawberry & -1.62 & 0.27 & -0.11 & 0.26 \\
\hline Herbstfreude & -0.83 & 0.85 & -0.42 & -0.72 & Späte Leopold & -1.10 & 1.46 & -0.80 & 1.26 \\
\hline Herzbergs Triumph & -1.30 & 0.77 & 0.51 & 1.29 & Sturms Zuckersüße & -0.72 & 0.08 & 1.39 & 1.88 \\
\hline Hildegard Pötschke & -0.79 & 0.09 & 0.90 & 0.76 & Symphony & 1.46 & 1.11 & -0.52 & 0.04 \\
\hline Honeoye & 1.37 & 0.78 & -0.59 & -0.38 & Tabea & 1.08 & 1.62 & 0.23 & 1.11 \\
\hline Jena 3 & -0.94 & -0.60 & -0.41 & -0.56 & Talisman & -0.28 & -0.22 & 0.13 & 0.47 \\
\hline
\end{tabular}


Table 5

Continued

\begin{tabular}{|c|c|c|c|c|c|c|c|c|c|}
\hline \multirow[t]{2}{*}{ Cultivar } & \multicolumn{4}{|c|}{ Component scores } & \multirow[t]{2}{*}{ Cultivar } & \multicolumn{4}{|c|}{ Component scores } \\
\hline & $\mathrm{PC} 1$ & $\mathrm{PC} 2$ & PC3 & $\mathrm{PC} 4$ & & $\mathrm{PC} 1$ & $\mathrm{PC} 2$ & PC3 & $\mathrm{PC} 4$ \\
\hline Joghana & 0.28 & -0.76 & -1.64 & 1.29 & Thielesa & 0.06 & -1.10 & 1.16 & 0.34 \\
\hline Jucunda & -0.99 & -0.81 & -0.02 & -0.68 & Trumpeter & 0.11 & -2.02 & 0.31 & 0.83 \\
\hline Julyana & 0.10 & -0.47 & 1.76 & -1.31 & Weghorna & 0.24 & -1.83 & 0.32 & -0.29 \\
\hline Junimorgen & -1.47 & 1.27 & -0.50 & -1.30 & Weiße Ananas & -1.14 & -0.31 & -0.35 & -2.31 \\
\hline Kaisers Sämling & -0.72 & 0.82 & 0.42 & -2.77 & Wunder von Köthen & 0.22 & 0.77 & 0.29 & 1.01 \\
\hline Karla & 1.17 & 1.10 & -1.27 & 0.12 & Zarathustra & 0.26 & 0.55 & 1.01 & -0.67 \\
\hline
\end{tabular}

Table 6

Correlation coefficients among the descriptors and the year of origin of the cultivar (only significant correlations are mentioned)

\begin{tabular}{lc}
\hline Descriptor & Correlation coefficients \\
\hline Number of flowers per inflorescence & -0.31 \\
Stolons: number & -0.29 \\
Pedicel: brittleness & 0.23 \\
Lenght of picking season (d) & 0.24 \\
Fruit: uniformity of size & 0.25 \\
Terminal leaflet: shape of base & 0.27 \\
Fruit: color of flesh & 0.28 \\
Fruit: color & 0.28 \\
Time of flowering & 0.31 \\
Fruit: glossiness & 0.32 \\
Yield per plant (g) & 0.33 \\
Fruit: size (mm) & 0.34 \\
Juiciness & 0.38 \\
Fruit: firmness of the fruit flesh & 0.38 \\
\hline
\end{tabular}

have higher firmness, higher juiciness, bigger fruit size, higher yield, but the number of flowers per inflorescence and the number of stolons were reduced. The correlation coefficient for the flavour was -0.15 and hence not significant. Jensen and Toldam-Andersen could not find significant correlations or systematic changes but estimated tendencies only [29]. The current study included four times the cultivars as in the earlier studies and this is a likely reason for the difference in correlations.

PCA, one of the multivariate statistical procedures, was previously used to establish genetic relationships among fruit cultivars and to study correlations among traits within sets of genotypes [4-6, 8, 16]. Associations between traits emphasized by this method may correspond to genetic linkage [21]. While studies in apricots [4-6] and sour cherries [16] found a cumulative variability between 56 to $71 \%$ for the first three components, the present results revealed a value of $30 \%$ (Table 3 ) corresponding exactly to the data of Pereira-Lorenzo and co-workers for apple [8]. Normally the number of genotypes investigated ranges from 16 to $55[4,6,16]$ and the number of traits between eight and $26[4-6,16]$. The analysis of 408 accessions representing the apple germplasm from Northwestern Spain evaluated 49 variables and a high inter- and intracultivar variability was found [8]. The present data account for a high diversity among the investigated strawberry cultivars representing a time frame of origin of 146 years and the geographical distribution from Germany (70\% of the cultivars), Europe and Canada/USA (8\%). Using the main sources of variability found with PCA (Table 4), a preliminary classification can be drawn from the results based on easily recognizable characteristics. A comprehensive evaluation would include the following descriptors: (1) yield, plant habit, firmness, (2) fruit size, time of ripening, stolon number, flower size (3) time of flowering, leaf 
color, (4) fruit characteristics like color, flesh color, band without achenes, insertion of calyx, and size of calyx in relation to the fruit diameter. Similar analyses in Fragaria wild species accessions, leaf, flower and stolon descriptors resulted in higher significance [24, 30]. The first grouping of the cultivars could be derived from scores for the first four principal components (Table 5). Further cluster analysis could be realized by joining information about morphological characters and any molecular biological analysis. Horvath and co-workers [31] identified four sub populations of the genetic structure of 87 strawberry genotypes by Bayesian analyses of 23 SSR-Markers. Twenty two of the cultivars in the current study were included in the genetic study of Horvath et al. [31] and representatives of all 4 sub populations could be identified. For further evaluation of strawberry cultivars, analyses of fruit nutritional compounds like antioxidant capacity, polyphenols and anthocyans [32] and the evaluation of disease resistance would be of great importance [33,34].

The phenotypic variability observed was higher than expected in the cultivars investigated as part of the germplasm collection in Dresden. The greater number of genotypes represents the many diverse breeding histories of the past 150 years, but from limited geographical origins. This analysis provides valuable information about the cultivated strawberry Fragaria $\times$ ananassa. About $50 \%$ of the evaluated strawberry cultivars were bred before 1970 and only $15 \%$ of the cultivars originated after 1970 , the time period characterized by the accelerated loss of alleles [31]. Therefore, this study of the present germplasm collection may be advantageous for breeding purposes. The requirements for improved cultivars are diverse, depending on the use of the varieties and the level of the value-added in the chain from production of the fruits to consumption of the product. The germplasm cultivar collection has good candidates to fit these needs based on the morphological descriptors: yield, fruit characteristics and ripening. However, the important characteristics are split among diverse germplasm sources. Hybridization will be necessary to combine the desired quality characteristics. With the publication of the first linkage studies in octoploid strawberry a milestone was reached to take classical strawberry breeding to a new level. The availability of DNA markers linked to QTLs, as well as cloning of individual genes that significantly contribute to complex traits, will be very helpful for breeders to select for a specific introgression of traits of interest [35].

This study was undertaken to determine pomological and phenological characteristics of a cultivar sub-set of the strawberry germplasm collection belonging to the Fruit Genebank of the Julius Kühn-Institute, Institute for Breeding Research on Horticultural and Fruit Crops in Dresden. The correlation analysis (Table 2) and the PCA (Table 4) suggest that a relatively high number of descriptors are necessary for further comprehensive evaluation projects. The morphological analysis marked out the most useful characters for further accession description and core collection development $[9,12,13]$. Discrimination between cultivars could be assigned to the following primary descriptors: (1) for plant morphology - habit, leaf color upper side and glossiness, time of appearance of first stolons; (2) for the flower - sex and time of flowering; (3) for the fruit - shape, color, coloration type, band without achenes, insertion of calyx, size of calyx, firmness, color of flesh, hollow center and time of ripening. All descriptors that are very strongly influenced by environmental conditions (yield and correlated characters and fruit size) should be investigated as secondary descriptors in a more detailed experiment. Phenological data, time of flowering and ripening which are characterized by high eigenvectors (Table 4) are of great importance especially in the context of climate change [36]. Use of these suggested descriptors will improve the evaluation of strawberries for plants in many growth conditions as in the permanent germplasm collection, orchard, and greenhouse and box system in the orchard. Bottlenecks for study such as having enough plants per cultivar of the same quality for a field trial, could be reduced and perennial evaluation of the same plant material would be possible. The same classification of descriptors was proposed as appropriate primary and secondary descriptors for the European GENBERRY project of the cultivated octoploid strawberry (Fragaria x ananassa Duch.).

\section{References}

[1] Hannum S, Potential impact of strawberries on human health: A review of the science. Nutritional Sciences. $2004 ; 44: 1-17$.

[2] Hummer K, http://www.croptrust.org/main/strategies.php?itemid=382008.

[3] Lacic G. Morphological analysis of Latvian sweet cherry (Prunus avium L.) genetic resources collection. In: Swiecicki W, Naganowska B, Wolko B, editors. Broad variation and precise characterization - Limitation for the future. EUCARPIA, Poznan; 2001 : pp. 225-8.

[4] Badenes ML, Martinez-Calvo J, Llacer G. Analysis of apricot germplasm from the European ecogeographical group. Euphytica. 1998; 102: 93-9. 
[5] Asma BM, Ozturk K. Analysis of morphological, pomological and yield characteristics of some apricot germplasm in Turkey. Genetic Resources and Crop Evolution. 2005; 52: 305-13.

[6] Ruiz D, Egea J. Phenotypic diversity and relationships of fruit quality traits in apricot (Prunus armeniaca L.). Euphytica. 2008; 163 : 143-58.

[7] Krahl KH, Lansari A, Iezzoni AF. Morphological variation within a sour cherry collection. Euphytica. 1991; 52: 47-55.

[8] Pereira-Lorenzo S, Ramos-Cabrer AM, Ascasibar-Errasti J. Analysis of apple germplasm in Northwestern Spain. J Amer Soc Hort Sci. 2003; 128: 67-84.

[9] Santesteban LG, Miranda C, Royo JB. Assessment of the genetic and phenotypic diversity maintained in apple core collections constructed by using either agro-morphologic or molecular marker data. Spanish Journal of Agricultural Research. $2009 ; 7: 572-84$.

[10] Flachowsky H, Höfer M. The German Fruit Genebank, a decentral network for sustainable preservation of fruit genetic resources. Journal für Kulturpflanzen. 2010; 62: 9-16.

[11] Höfer M, Reed B. Cryopreservation of strawberry genetic resources in Germany. Acta Hort. 918: 139-46.

[12] Brown AHD. Core collections a practical approach to genetic resources management. Genome. 1989; 31: 818-24.

[13] van Hintum TJL, Brown AHD, Spillane C, Hodgkin T. Core collections of plant genetic resources. IPGRI Technical Bulletin. 2000 ; No. 3.

[14] UPOV. Guidelines for the conduct of tests for distinctness, uniformity and stability (Strawberry). TG/22/9. 1995.

[15] IBPGR. Strawberry descriptors (Fragaria L.) International Board for plant genetic resources, Rome. 1986.

[16] Hillig KW, Iezzoni AF. Multivariate analysis of sour cherry germplasm collection. J Amer Soc Hort Sci. 1988; 113: 928-34.

[17] Hussaini SH, Goodman MM, Timothy DH. Multivariate analysis and the geographical distribution of the world collection of finger millet. Crop Science. 1977; 17: 257-63.

[18] Martin GB, Adams MW. Landraces of Phaseolus vulgaris (Fabaceae) in Northern Malawi. I. Regional variation. Economic Botany. 1987; 41: 190-203.

[19] Elhoumaizi MA, Saaidi M, Oihabi A, Cilas C. Phenotypic diversity of date-palm cultivars (Phoenix dactylifera L.) from Morocco. Genetic Resources and Crop Evolution. 2002; 49: 483-90.

[20] Geibel M, Roudeillac P. Genetic resources in strawberries in Europe. Acta Horticulturae. 2000; 538: 109-11.

[21] Iezzoni AF, Pritts MP. Applications of principal component analysis to Horticultural Research. HortScience. 1991; 26: 334-8.

[22] Staudt G. Les dessins d'AN. Duchesne pour son Histoire naturelle des fraisiers. Publications Scientifiques du Museum, Paris. 2003 ; 16-27.

[23] Korona VV, Dubrovnaya SA. A method for evaluating the morphological diversity of strawberry leaves in natural populations. Russian Journal of Ecology. 2001; 32: 203-5.

[24] Jensen RJ, Hancock JF Jr. Multivariate relationships among California strawberries. Bulletin of the Torrey Botanical club. 1982; 109: $136-47$.

[25] Luby JJ, Hancock JF, Dale A, Serce S. Reconstructing Fragaria $\times$ ananassa utilizing wild F. viriginiana and F. chiloensis: Inheritance of winter injury, photoperiod sensitivity, fruit size, female fertility and disease resistance in hybrid progenies. Euphytica. $2008 ; 163: 57-65$.

[26] Faedi W, Baruzzi G, Lovati F, Sbrighi P, Lucchi P. Monografia di cultivar di fragola. Progetto finalizzato MiPAF 'Liste di orientamento varietale dei fruttiferi' Roma. 2002; 201.

[27] Krüger E, Schulte E. Neue Erdbeersorten - gibt es Alternativen zur Standardsorte 'Elsanta'? Obstbau 2002; 7: 353-7.

[28] Helm HU, Schilling K. Erdbeer-Sortenprüfung 2001 in Weihenstephan. Obstbau 2002; 10: 504-6.

[29] Jensen SL, Toldam-Andersen TB. Evaluation of 27 strawberry cultivars grown in Denmark over more than 150 years. External quality Acta Horticulturae. 2004; 649: 151-8.

[30] Sargent DJ, Geibel M, Hawkins JA, Wilkinson MJ, Battey NH, Simpson DW. Quantitative and qualitative differences in morphological traits revealed between diploid Fragaria species. Annals of Botany. 2004; 94: 787-96.

[31] Horvath A, Sanchez-Sevilla JF, Punelli F, Richard L, Sesmero-Carrasco R, Leone A, Höfer M, Chartier P, Balsemin E, Barrenech T, Denoyes B. Structured diversity in octoploid strawberry cultivars: Importance of the old European germplasm. Annals of Applied Biology. 2011. ISSN 0003-4746: 1-14.

[32] Diamanti J, Sguigna V, Capocasa F, Denoyes B, Petit A, Chartier P, Faedi W, Maltoni ML, Battino M, Mezzetti B. Developing a standardized method for the evaluation of strawberry (Fragaria x ananassa Duch.) germplasm collection as genetic resource of fruit nutritional compounds (submitted)'.

[33] Maas JL, (eds.). Compendium of strawberry diseases. St. Paul: APS Press; 1984.

[34] Jęcz T, Korbin M. Inoculation of micropropagated plants with wounded roots as a tool to precisely distinguish strawberry genotypes tolerant and susceptible to Verticillium wilt disease. Phytopathologia. 2010; 58: 33-42.

[35] Flachowsky H, Höfer M, Hanke V. Strawberry. Fruit, Vegetable and Cereals Science and Biotechnology. 2011; 5: 8-26.

[36] Legave JM, Giovannini D, Christen D, Oger R. Global warming in Europe and its impacts on floral bud phenology in fruit species. Acta Hort. 2009; 838: 21-6. 